\title{
INTERNATIONAL TRADE RELATIONSHIPS IN EU COUNTRIES THROUGH MULTIDIMENSIONAL SCALING DURING THE YEARS 1996-2012
}

\author{
Ingrida Grigonyte $\dot{e}^{1}$, Fernando Garcia ${ }^{2}$, Javier Oliver ${ }^{3}$ \\ ${ }^{1}$ Faculty of Business Management, Vilnius Gediminas Technical University, Sauletekio al. 11, Vilnius, Lithuania \\ ${ }^{2,3}{ }^{3}$ Universitat Politecnica de Valencia, Campus de Vera, Camino de Vera, Valencia, Spain

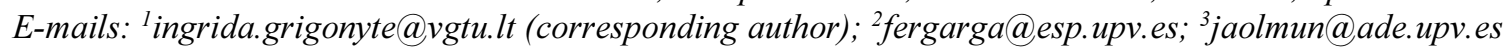

\begin{abstract}
International trade is one of the most important parts of economic integration and globalization. Thus it is crucial to study the development of international trade relationships in order to follow and understand every score and reasons behind it. In this article, multidimensional scaling analysis is performed in order to investigate the evolution of international trade relationships in the EU countries in 19962012. The results show that the evolution of trade relationships among EU countries is not entirely homogeneous. Different country groups arise regarding different variables, such as geographical location or being former members of the same economic or political union.
\end{abstract}

Keywords: International trade, multidimentional scaling, trade evolution, European Union.

JEL Classification: A1; F00; F1; F15.

\section{Introduction}

Globalization is referred to as a process when countries become more dependant on each other, and this dependance rises from higher trade integration, free movement of people among the countries, integrated finance systems, shared ideas and global marketplace. World bank states that international trade is one of the main parts of this integration. Many researchers agree that international trade is one of many important conditions for globalization and welfare of nations.

Late episodes of globalization can be described through trade integration, movement of employees and flows of capital, though the importance of all these elements are different regarding the regions, countries and continents.

Quick review of international trade history reveals that after World War II there was a long period of development, world merchandise exports increased by eight percent annually. Later growth of trade decreased because of the influence of oil price shock and increased inflation, which was caused by monetary expansion and inappropriate macroeconomic adjustment policies.

In the 1990s, the expansion of trade was more rapid, innovations and the sector of information technology played their part in the expansion. Average trade expansion for period 2000-2007 was 6 percent. For the period 1950-2000 trade expanded by 6.2 percent (World Trade Organization 2016).
In the last few decades international trade was liberalised more than ever, integration was stimulated quite extremely and many markets became more integrated (Martinez-San Roman et al. 2015; Martinez et al. 2012; Yoto 2012). Adoption of business arrangements and economic - region integration can be one of the necessary actions in globalization process and can save fast-developing economies from severe competition on global scale (Naveh et al. 2012) under specific conditions.

Countries that participate intensely in foreign trade can take benefit from producing to larger foreign markets and from international labour division. These countries also almost definately meet stronger competitors in foreign markets and have the need for bigger improvement and higher innovation. Because of increased competition companies produce more efficiently and consumers also gain benefits from a wider variety of goods at lower prices (World Bank 2016).

In addition, an actively trading country can benefit from the new technologies that "spill over" to it from its trading partners, such as through the knowledge placed in imported production equipment. This "spill over" effect of innovations and new knowledge is very important for developing countries. It gives the opportunity for less developed countries to reach more developed level.

It is crucial to investigate the development of international trade relationships in order to follow

(C) 2016 The Authors. Published by VGTU Press. This is an open-access article distributed under the terms of the Creative Commons Attribution License (CC-BY 4.0), which permits unrestricted use, distribution, and reproduction in any medium, provided the original author and source are credited. 
and understand every score and reasons behind it and under which conditions the benefits mentioned above do actually occur. The main goal of this reserach is to investigate the evolution of trade among European Union members.

The purpose of the research is to investigate the evolution of international trade in EU countries during period 1996-2012.

Tasks of the article are as follows:

- To make analysis of papers of other researchers in order to investigate the level of the explored problem.

- To make multidimentional scaling analysis in order to reveal the evolution of international trade in EU.

- To make the analysis of the results and to present conclusions.

Object of the research is international trade among EU countries.

Methods used in this research are: context analysis, comparative analysis, generalization analysis, multidimentional scaling, deduction and induction methods.

\section{Benefits and obstacles of international trade}

When exploring the genesis, findings and conclusions made by other researchers on international trade, it is clear that most researchers and economists highlight comparative advantage, consumer's aspiration to use variety of goods, and increasing returns to scale (Bernard et al. 2007).

The movement of goods among countries is explained by traditional theories of international trade, in this explanation comparative advantage is used. Comparative advantage can appear because of the differences of productivity as well as because of the cross-industry differences in factor intensity and abundance.

Traditional trade theory states that trade among countries is inter-industrial - countries will export goods from one industry and import goods from another industry (Bernard et al. 2007).

Grubel and Loyd (1975) state that a big share of international trade is among similar partners, and usually inside industries. Bernard et al. (2007) give an example of such trade - Germany and United States of America with their automotive industry, trading cars between themselves.

Such observations gave roots for new trade models created by Ethier (1982), Helpman (1981; 1999), Krugman (1980), Helpman, Krugman (1985). In contrast to old trade theories, where the benefits arise from the diversity in opportunity costs of production through industries and coun- tries, "new" theory of trade have gains of welfare developing from the greater diversity of goods that becomes available to consumers (Bernard et al. 2007).

In the old trade theory, the welfare gains from trade are due to specialization according to comparative advantage. In the new trade theory, the benefit from international trade arises from economies of scale and the greater diversity of goods that are available to the consumer (Vanagas 2013).

There are a lot of research confirming that more liberate trade increases aggregate productivity, especially in developing countries (Tybout 2003; Pavcnik 2002). Also research confirms (Trefler 2004) that free trade agreements raise labour productivity. Bernard et al. (2006) found evidence that supports connection between lowering costs of trade and within-plant productivity increase in the U.S.

Quite similar templates of gains in productivity have been found in Canada (Trefler 2004) and the U.S. (Bernard et al. 2006) in response to decreasing trade barriers. These gains arise from the growth of highly productive exporting companies. Following all these studies it could be concluded that there are many benefits to be obtained from free trade.

More and more evidence shows that liberalization of trade causes faster output and growth of employment among highly-productive exporting companies inside an industry. Part of results show the impact of trade liberalization on productivity of companies. This impact seems to be less expressed but nevertheless important (Bernard et al. 2007). It reveals that trade without barriers is beneficial for the economy of countries, developing and developed alike.

However, it seems that international trade patterns are not as homogenous as they could be. In the nineties researchers already stated that nations appear to trade too little with each other (Helliwell 1997; McCallum 1995; Trefler 1995).Eaton and Kortum (2002) calculated that removing all geographic barriers to trade, the so called ,zero gravity" situation, would lead to a more than five times increase in world trade. However this did not happen and there are a lot of attempts to explain the "missing trade" puzzle. These attempts seem to be focused on informal barriers of trade, insufficient information on possibilities of international trading and weak implementation of international agreements.

Processes of increasing globalization, free trade treaties and agreements, European integration, lead to the expected result that borders should 
have almost no impact on trade. However, border effects are being observed; this is explained as the extent by which the scope of domestic trade exceeds the scope of international trade (Evans 2003).

However the differences of prices still exist in the EU market regardless of market integration (Engel, Rogers 2006). These price diferences might be related to the distance between countries (Crucini et al. 2003)

High border effects were estimated by McCallum (1995) between US and Canada. Soon the border effect was named as one of the main puzzles in international economics (Obstfeld, Rogoff 2000). Various researchers of international trade tried to find why the observed border effects are higher than they should be (Vanagas 2013). Most thoroughly studied reasons were problems in the methodology (Anderson, Wincoop 2003; Head, Mayer 2002; Nitzch 2000), trade barriers (Chen 2004; Head, Mayer 2000; Wolf 2000; Hillberry 1999; Wei 1996) and preference of domestic goods against imported goods (Evans 2003).

One of the cornerstones of the European Union is the idea of a single market; there have been no tariffs or quotas within the EU since 1968. Even more, the European Commission has passed policies, such as the Single Market Programme, in order to eliminate trade barriers and in order to stimulate integration of the market (Vanagas 2013; Head, Mayer 2000).

Some researchers describe a consumer behaviour called consumer ethnocentrism, which is a preference of domestic goods because consumers assume that if they buy imported goods the domestic economy will suffer (Vanagas 2013; Shimp, Sharma 1987). Vanagas (2013) and Balabanis et al. (2001) research nationalism/patriotism and consumer ethnocentricity. The research by Vanagas (2013) show that a large part of border effects can be explained by cultural dimensions and nationalism of the consumers.

In conclusion, after thorough analysis of scientific literature, it is clear that economic integration in the form of international trade can bring many benefits for all the related parties: companies, labourers, consumers and economy as a whole in forms of international labour division, greater competition, higher innovation, wider variety of goods, comparative advantage, increasing returns of scale, etc.

However, difficulties in the process of trade integration are being observed. Research performed to date reveals the "puzzle of missing trade" or border effects, and attempts to explain it.
Investigations performed by other researchers suggest the following explanations: insufficient information on possibilities of international trade, weak implementation of international agreements, problems in the methodology or consumer ethnocentrism. These investigations were carried out across the globe. However there is only a small volume of research regarding the evolution of trade in European Union since the 1990s.

The authors of this paper carried out research using data of international trade in the European Union during the period 1996-2012.

In the following chapter the results of multidimentional scaling analysis are presented. The evolution of trade among EU countries and homogeneity of the international trade in EU is analysed.

\section{International trade relationships in $\mathbf{E U}$ countries through multidimensional scaling}

In this research the method of multidimentional scaling was used, which allows to explain the observed similarities or dissimilarities (distances) among the investigated objects.

The results are depicted in a two-dimentional distance matrix.

The data used in the research regarding international trade was taken from the database of the World Bank. The GDP data was taken from the Eurostat database. The countries that were included in the analysis are listed below (see Table 1).

Table 1. Countries whose data was analysed in the research (Source: created by authors)

\begin{tabular}{l|c|l|c}
\hline $\begin{array}{l}\text { Name of the } \\
\text { country }\end{array}$ & $\begin{array}{c}\text { Abbre- } \\
\text { viation }\end{array}$ & $\begin{array}{l}\text { Name of the } \\
\text { country }\end{array}$ & $\begin{array}{c}\text { Abbre- } \\
\text { viation }\end{array}$ \\
\hline Austria & AU & Latvia & LV \\
\hline Belgium & BE & Lithuania & LT \\
\hline Bulgaria & BG & Luxembourg & LU \\
\hline Cyprus & CY & Malta & MT \\
\hline $\begin{array}{l}\text { Czech } \\
\text { Republic }\end{array}$ & CZ & Netherlands & NT \\
\hline Denmark & DK & Poland & PL \\
\hline Estonia & EE & Portugal & PT \\
\hline Finland & FI & Slovakia & SK \\
\hline France & FR & Slovenia & SL \\
\hline Germany & DE & Spain & ES \\
\hline Greece & GR & Sweden & SE \\
\hline Hungary & HU & United Kingdom & UK \\
\hline Ireland & IE & Romania & RO \\
\hline Italy & IT & & \\
\hline & & &
\end{tabular}


The period between 1996-2012 was chosen according to the availability of the data for all the countries. An interval of four years was chosen in order to show the evolution of trade more vividly, and because of limited scope of pages of the paper.

The countries were arranged into pairs. International trade was divided by the GDP at market prices for each country pair in order to eliminate the effect of the country size to the results.

In the multidimensional scaling graph of international trade among EU countries in the year 1996 (see Fig. 1), the countries are quite scattered in the graph.

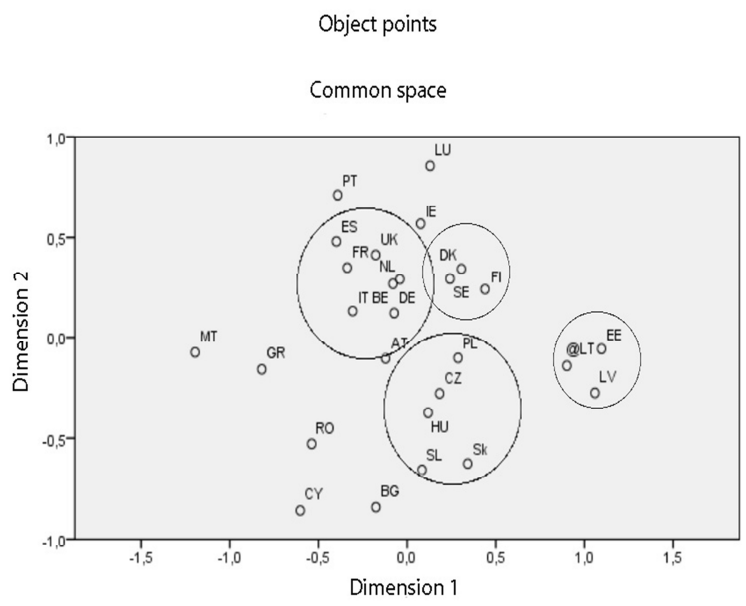

Fig. 1. Multidimensional scaling of international trade in EU in 1996 (Source: created by the authors)

However some clusters can be observed. Closest to each other in the cluster are the founding nations of EU - France, Netherlands, Italy, Belgium and Germany, also close to them are United kingdon, which joined the EU quite early (in 1973), Spain, which joined the EU in 1986, Portugal (joined in 1986) and Austria (joined in 1995). All these countries also are close to each other geographically, or even have mutual borders. These countries form the biggest, main cluster almost in the center of the graph.

Another group are Denmark, Sweden and Finland - Scandinavian countries that share similar cultural traits, history and participated in various agreements and treaties the past, starting with the Kalmar Union in the 14th century.

This cluster of Scandinavian countries is quite close to the main cluster of founding nations (France, The Netherlands, Italy, Belgium, Germany).

One more group is Poland, Czech Republic and Hungary. Poland, Hungary, Czech Republic together with Slovakia and Slovenia was socialist states. Some of these countries also share mutual borders. Quite close to them is Bulgaria.
There is one separate and very distinctive cluster which consists of the Baltic states - Lithuania, Latvia, and Estonia. These countries belonged to the former Soviet Union, and they share mutual borders in addition to being very similar in culture. However they are quite far from other countries that belonged to Soviet Union or were socialist states (such as Czech Republic, Bulgaria or Romania). It seems that geography plays quite an important role in this case.

Baltic states are further from the main cluster than any other cluster. They also are far from other clusters.

Quite a few countries seem to be scattered away from the main groups: these are Malta, Greece, Romania, and Cyprus. They are apart from other countries and from each other. It might be inferred that the geographic variable plays the main part here, because these countries (especially Malta and Cyprus) are geographically distant from other members of the EU. They are also islands which makes them less accessible.

However, Romania, Bulgaria and Greece are close geographically, but they are far from each other in the graph. This might be explained by the harsh historical past in this region. Bulgaria, which is positioned between Romania and Greece fought against the latter two in the Balkan Wars at the beginning of the 20th century. Later Bulgaria and Romania were socialist states.

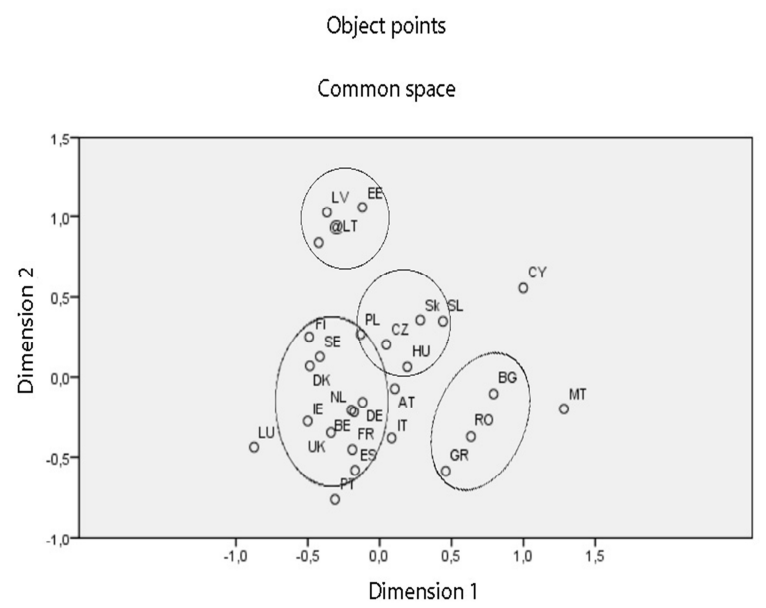

Fig. 2. Multidimensional scaling of international trade in EU in 2001 (Source: created by the authors)

In the year 2001 (see Fig. 2) country groups are a little more distinct than in the year 1996, the trade seems to be more segmented among EU countries. The biggest (main) group consists of countries Finland, Sweden, Denmark, Netherlands, Ireland, United Kingdom, Spain, Germany, France, Portugal, Italy. The heart of the group, as in the 
previous investigated year, are the founder countries, and quite close to them are the countries that joined the EU early or have mutual borders. The trade is intense among these countries.

However, the Scandinavian countries (Finland, Sweden and Denmark) still seem to be closer to each other than rest of the group in 2001. They are noticebly closer to the founding countries than in year 1996, but still not fully integrated in the trade among them.

In 2001 (see Fig. 2) Poland, Czech Republic, Hungary, Slovakia and Slovenia still are apart from the main group, but considerably closer than in the year 1996. This might show stronger integration in international trade but still not complete integration. Bulgaria, Romania and Greece are closer together, yet quite far apart from the main group.

The Baltic states in 2001 still remain separate from other groups and close to each other, their position almost didn't change relative to other countries from 1996. This reveals poor integration of Baltic states into the international trade of the EU.

The most scattered countries are still Malta and Cyprus. As mentioned before, they are quite far geographically from other countries and this separation might be explained also by their small size and more difficult communication with other EU countries due to being islands in the Mediterranean sea.

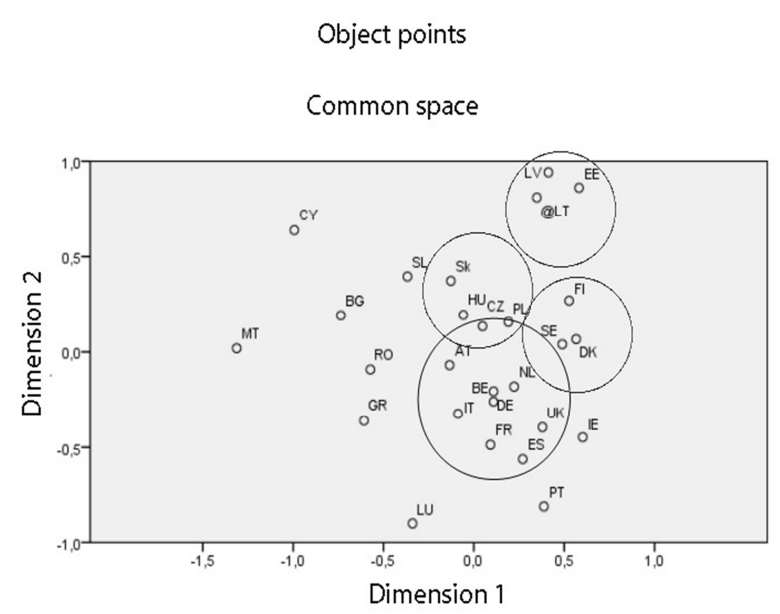

Fig. 3. Multidimensional scaling of international trade in EU in 2006 (Source: created by the authors)

In the year 2006 (see Fig. 3) the countries in the graph are again more scattered than in the year 2001. This reveals that the process of trade integration is not uniform.

However, as in previous year, several clusters can be observed. As in previous years, the main group consists of EU founding members: $\mathrm{BE}, \mathrm{DE}$, NL, IT, FR. Quite close to these are ES and UK, also old members of the EU. Spain is also close geographically to the founding members. Furthermore, all these countries are the biggest ones in terms of GDP.

Once again there is a well defined, separate cluster of the Baltic States that are quite far from the other countries in 2006 (see Fig. 3). Hungary, Czech Republic and Poland are again closer to one another than to other countries, they are quite far apart from main group members. Sweden, Denmark and Finland also are closer to one another than in the previous investigated year, and apart from the main group. This again confirms the case of volatile trade integration process. Bulgaria, Romania and Greece are again far apart from the main group. Most scattered countries are again Cyprus and Malta.

In the year 2012 (see Fig. 4) many countries that were separate earlier form a somewhat unified single cluster. However the EU founding countries still can be distinguished being closer to each other than to other countries, especially those who joined the EU quite recently.

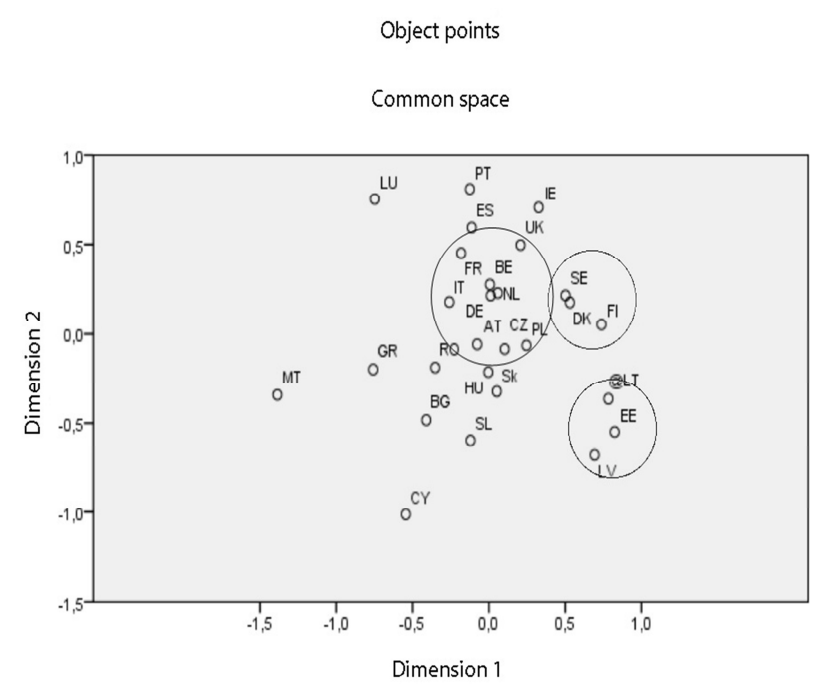

Fig. 4. Multidimensional scaling of international trade in the EU in 2012 (Source: created by the authors)

In 2012 the Baltic states are a little bit closer to the other cluster, however, they still form a distinctive separate cluster. Also Sweden, Denmark and Finland form a separate group. Greece, Bulgaria and Slovenia are closer to the main group than before, however still remain clearly separate from it.

Malta and Cyprus remain most distant from the other EU countries.

These observations suggest the conclusion that international trade in the EU is not homogeneous. There are clear separate groups of countries that trade much more intensely among themselves 
than with other EU members. Almost the same pattern of clusterization with slight shifting remains during the whole period (1996-2012). These results are quite troubling and reveal that trade integration and evolution in the EU is slower than anticipated.

When analysing country groups it is clear that EU founding countries along with the countries that joined the EU early form a separate group, quite distinctive from other country groups.

The analysis suggests that countries cluster based on such variables as: their previous trading history (Scandinavian countries, EU founding countries), earlier unions (Baltic States, Scandinavian countries), or geographical position (Malta, Cyprus, EU founding countries, Baltic States) and economic size (Germany, France, Italy, Spain). All these variables intertwine together and can be observed among variuos country groups.

Further research is needed to determine how much these variables affect each country group.

\section{Conclusions}

The analysis of scientific literature reveals that free international trade is beneficial for the economies of the participating countries in many respects and trade integration is an important factor of globalisation. However there seem to be troubles regarding the process of international trade integration across the globe. A lack of research is perceived regarding evolution of trade in the EU during the last two decades.

The research reveals that international trade in the EU is not homogeneous. There are clear separate groups of countries that trade much more intensely among themselves, than with other EU members. These results are troubling and reveal that trade integration and evolution in the EU is slower than anticipated. Such situation prevents less integrated countries from benefitting in full from international trade.

When analysing country groups it is clear that EU founding countries along with the countries that joined the EU early form a separate group, quite distinctive from other country groups. This reveals that older EU members trade more among themselves than with other countries, especially with new ones. This might be a signal that more effective integration for recent members of the EU is needed.

The analysis suggests that country clusters are based on such variables as: their previous trading history (Scandinavian countries, EU founding countries), earlier unions (Baltic States, Scandina- vian countries), geographical position (Malta, Cyprus, EU founding countries, Baltic States) and economic size (Germany, France, Italy, Spain). All these variables intertwine together and can be observed among various country groups. Further research is needed to determine how much each of these variables affects each country group. In this context, applying a gravitational model could be of interest to describe the interrelation among variables and their relative importance in the evolution of trade within the EU.

The reason why trade in the EU is not homogeneous might also be because of "border effect". The reasons for this effect might be, as literature analysis suggests, informal trade barriers, like price differences in different countries, and consumers favouring domestic goods above foreign ones. However, wider research is needed to confirm this implication.

\section{References}

Anderson, J. E.; Wincoop, E. 2003. Gravity in gravitas: a solution to the border puzzle, The American Economic Review 93(1): 170-92. http://dx.doi.org/10.1257/000282803321455214

Balabanis, G., A; Diamantopoulos, R. D.; Melewar, T. C. 2001. The impact of nationalism, patriotism and internationalism on consumer ethnocentric tendencies, Journal of International Business Studies 32(1): 157-175.

Bernard, B. A.; Jensen, J. B.; Redding, S.; Schott, P. K. 2007. Firms in international trade, Journal of Economic Perspectives 21(3): 105-130. Available from Internet: http://www.princeton.edu/ reddings /pubpapers/FirmsTradeJEP2007.pdf

Bernard, A. B.; Bradford J.; Peter K. S. 2006. Trade costs, firms and productivity, Journal of Monetary Economics 53(5): 917-937. http://dx.doi.org/10.1016/j.jmoneco.2006.05.001

Crucini, M. J.; Telmer, C. I.; Zachariadis, M. 2003. Price dispersion: the role of borders, distance and location. Tepper School of Business paper 490 [online], [cited 01 March 2016]. Available from Internet: http://repository.cmu.edu/cgi/viewcontent .cgi? article $=1490 \&$ context $=$ tepper

Chen, N. 2004. Intra-national versus international trade in the European Union: Why do national borders matter, Journal of International Economics 63(1): 93-118.

http://dx.doi.org/10.1016/S0022-1996(03)00042-4

Eaton, J.; Kortum, S. 2002. Technology, geography and trade, Econometica 70(5): 1741-1779 [online], [cited 05 March 2016]. Available from internet: http://www.princeton.edu/ erossi/courses_files/EK n.pdf 
Ethier, W. J. 1982. National and international returns to scale in the Modem theory of international trade, American Economic Review 72: 389-405.

Engel, C.; Rogers, J. H. 2006. Deviations from purchasing power parity: causes and welfare costs, Journal of International Economics 55: 29-57.

http://dx.doi.org/10.1016/S0022-1996(01)00094-0

Evans, C. L. 2003. The economic significance of national border effects, The American Economic Review 93(4): 1291-312.

http://dx.doi.org/10.1257/000282803769206304

Grubel, H. G.; Lloyd P. J. 1975. Intra-industry trade: the theory and measurement of international trade in differentiated products, The Economic Journal 85(339): 646-648.

http://dx.doi.org/10.2307/2230917

Helliwell, J. F. 1997. National borders, trade and migration, National Bureau of Economic Research, Working Paper 6027 [online], [cited 01 March 2016]. Available from Internet: http://www.nber.org/papers/w6027.pdf

Head, K.; Mayer, T. 2002. Illusory border effects: distance mismeasurement inflates estimates of home bias in trade. Paris: CEPII Research Center.

Head, K.; Mayer, T. 2000. Non-Europe: the magnitude and causes of market fragmentation in Europe, Weltwirtshcaftliches Archiv 136(2): 285-314.

Helpman, E. 1999. The structure of foreign trade, Journal of Economic Perspective 13(2): 121-144. http://dx.doi.org/10.1257/jep.13.2.121

Helpman, E. 1981. International trade in the presence of product differentiation, economies of scale, and monopolistic competition: a Chamberlin-Heckscher-Ohlin model, Journal of International Economics 11: 305-340.

Helpman, E.; Krugman, P. 1985. Market structure and foreign trade: increasing returns, imperfect competition and the international economy. Cambridge, MA: MIT Press.

Hillberry, R. 1999. Explaining the "border effect": what can we learn from disaggregated commodity flow data. Indiana University Graduate Student Economics Working Paper Series 9802. Indiana University.

Yoto, V. Y. 2012. A simple solution to the distance puzzle in international trade, Economics Letters 117(3): 794-798. http://dx.doi.org/10.1016/j.econlet.2012.08.032

Krugman, P. 1980. Scale Econo mies, product differentiation, and the pattern of trade, American Economic Review 70: 950-959.

Martinez, V.; Bengoa, M.; Sanchez-Robles, B. 2012. Foreign direct investment and trade: complements or substitutes? Empirical evidence for the European Union, Technology and Investment 3: 105-112. http://dx.doi.org/10.4236/ti.2012.32013

Martinez-San Roman, V.; Bengoa, M; SanchezRobles, B. 2015. Foreign direct investment, trade integration and the home bias: evidence from the European Union, Empirical Economics 50(1): 197229. http://dx.doi.org/10.1007/s00181-015-0942-y

McCallum, J. 1995. National Borders matter: CanadaUS regional trade patterns, American Economic Review 85(3): 615-623.

Naveh, H. M.; Torosyan, T.; Jalaee, S. A. 2012. Regional economic integration and its effects on economic growth and economic welfare, World Applied Sciences Journal 17(10): 1349-1355.

Nitzch, V. 2000. National borders and international trade: evidence from European Union, Canadian Journal of Economics 33(4): 1091-1105. http://dx.doi.org/10.1111/0008-4085.00055

Obstfeld, M.; Roggoff, K. 2000. The six major puzzles in international macroeconomics: is there a common cause, National Bureau of Economics Research Paper 15: 339-412.

Pavcnik, N. 2002. Trade liberalization, exit, and productivity improvement: evidence from Chilean plants, Review of Economic Studies 69(1): 245-276. http://dx.doi.org/10.1111/1467-937X.00205

Shimp, T. A.; Sharma, S. 1987. Consumer ethnocentrism: construction and validation of the CETSCALE, Journal of Marketing Research 24(3): 280-289. http://dx.doi.org/10.2307/3151638

Trefler, D. 1995. The case of the missing trade and other mysteries, American Economic Review 85(5): 1029-1046.

Trefler, D. 2004. The long and short of the Canada-U.S. free trade agreement, American Economic Review 94(4): 870-895.

http://dx.doi.org/10.1257/0002828042002633

Tybout, J. 2003. Plant- and firm-level evidence on the 'new' trade theories, Chapter 13, in E. Kwan Choi, J. Harrigan (Eds.). Handbook of international trade. Oxford: Basil Blackwell.

Vanagas, M. 2013. Border effects among EU countries: do national identity and cultural differences matter, Reinvention: an International Journal of Undergraduate Research 6(2) [online], [cited 03 March 2016]. Available from Internet:

http://www2.warwick.ac.uk/fac/cross_fac/iatl/rein vention/issues/volume6issue2/vanagas/

Wolf, H. 2000. International Home bias in trade, The Review of Economics and Statistics 82(4): 555-563.

Wei, S. J. 1996. Intra-national versus international trade: how stubborn are nations in global integration. National Bureau of Economics Research Working Paper 5531.

Eurostat. 2016 [online], [cited 10 January 2016]. Available from Internet: http://ec.europa.eu/eurostat

World bank. 2016 [online], [cited 10 January 2016]. Available from Internet: http://www.worldbank.org/

World Trade Organization. 2016 [online], [cited 05 March 2016]. Available from Internet: https://www.wto.org/english/res_e/booksp_e/anrep _e/wtr08-2b_e.pdf 